\title{
直轄城下町甲府の都市空間
}

一武家地の分析を通して一

\section{A STUDY ON THE STRUCTURE OF THE SPACE OF KOFU CASTLE CITY UNDER THE DIRECT CONTROL OF THE TOKUGAWA SHOGUNATE \\ - Through an analysis of the samurai residencial area-}

\author{
岩本 馨* \\ Kaoru IWAMOTO
}

\begin{abstract}
Since 1724 , Kofu castle city had been ruled by Tokugawa shogunate vassals named Kofu-Kinban. In the beginning, because of its strategic importance, the space of the Kofu city was strongly controlled by Edo government, which was clearly seen in the banzuke (numbering) system of the samurai residential area. However, this Edo-centric system was absolutely inconsistent with the local logic of Kofu, and the structure of the city had to be changed gradually. This paper studied this change by analyzing how the banzuke system became meaningless.
\end{abstract}

Keywords: Kofu Kinban, Kofu Katte-Kobushin, samurai residential area, numbering system, Chokkatsu-Joka-Machi (Castle city under the direct control of the Tokugawa Shogunate) 甲府勤番、甲府勝手小普請、武家地、番付、直轄城下町

\section{1. はじめに}

近世都市の空間史的な研究において、地方都市を対象とした論考 はこれまで少なからず蓄積がなされてきた。しかしこうした論考が、 三都のような巨大都市を対象としたものほどに豊富な論点を提示し てきたかといえば疑わしいとせざるを得ないのが現状である。その 原因を筆者は、それらの多くが類型論の枠組みにとどまっており、 巨大都市において提示された論点との一致点・不一致点をケースス タディ的に確認しているに過ぎないからだと考える”。このような 状況を脱却するためには、まず中央対地方という単純な二項対立的 な枠組みから離执、都市相互の関係性の問題として捉え返すという 転換が求められているのではないだろうか。

本稿で扱う甲府という都市は、その意味で興味深い対象である。 一つには、この都市が享保 9 (1724)年以来幕府の直轄下におかれた という事実がある。幕府直轄化後の甲府には勤番制が敷かれ、江戸 から200名もの武士が集団で移住することになるが、これによって 彼らは「甲府藩士」となったわけではなく、身分的にはあくまでも 直参の幕臣であることに変わりはなかった。従って、甲府における 武家屋敷は江户におけるそれと原理的には等価であるはずで、そこ
に江戸の「飛び地」としての位相を認めることができるのである。 しかし一方で、直轄都市甲府は同時に、柳澤家の支配から引き継が れた2〕城下町甲府」でもあった。甲府の都市空間を支配する論理 は必ずしも幕府＝江戸の論理の延長であったばかりではなく、そこ には甲府という都市、或いはそれを中心とする地域自体が有する論 理も作用していたはずである。このような二重の論理こそが甲府と いう都市の特異な位相だったのであり、本稿ではその意味を込めて、 直轄化後の甲府を「直轄城下町」という言葉で把握したい3)。

本稿では特に武家地の空間に注目することで「直轄城下町」甲府 の問題について考察を加えるが、これは都市固有の論理と都市間の 関係性の論理との相克を考えることに他ならず、それを通して冒頭 での問題提起に対する筆者なりのアプローチを試みたい。

\section{2. 勤番制開始当初の甲府武家屋敷}

まずは甲府の直轄化の経緯について『徳川實紀』などの記事を参 考に簡単に見ておきたい4。。それまでの城主であった柳澤吉里に大 和郡山への転封の辞令が下ったのは享保 9 (1724)年 3 月 11 日のこ とである。これを承けるかたちで同28日に遠江浜松藩主松平豊後守
* 東京大学大学院工学系研究科建築学尃攻 大学院生・修士 (工学)
Graduate Student, Dept. of Architecture, Faculty of Engineering, Univ. of Tokyo, M. Eng. 
資訓が甲府城の守衛を命じられている。ついで 7 月 4 日に小普請組 支配であった有馬内䐣純珍および興津能登守忠閭の両名が甲府勤番 支配に任命され、8月11日には甲府勤番支配組頭 4名が、同13日に はこの 4 名を含む200名の勤番士が確定したのである5)。

甲府勤番の組織は大きく追手組と山手組に二分され、それぞれの 組は勤番支配 1 名と勤番士 100 名（組頭 2 名を含む）・与力 10 騎・同 心50名から構成されていた。この成立当初の一員については『甲府 勤番日記』 ${ }^{6)}$ その他の史料により全容を知ることができる。これに よると勤番支配は 3,000 石高・役地 1,000 石を与えられ、勤番士は 100 俵 10 人扶持から 500 石までの持高でつとめていたことが分かる。 勤番士の中からは組頭 4 名・仮目付 10 名・破損奉行 4 名・武具奉行 2 名・御蔵立合 2 名などが選出され、それぞれ手当が支給されてい た。屋敷については、勤番支配は甲府城郭内に役屋敷（追手・山手 1 箇所ずつ）を7)、勤番士も持高に応じた屋敷を拝領することとな つた。この際それまでの江戸屋敷については返上を命じられており

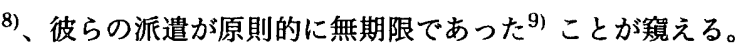

甲苻における择領屋敷の状況については上記『甲府勤番日記』と 「甲府城下絵図，10)とを照合することで知ることができる。「甲府 城下絵図」は現存する勤番制開始後の最も古い絵図であり、記載人 名からすると享保20(1735)年〜元文 4 (1739)年の状況を描いたも のと推定される ${ }^{11)}$ 。さて、これらの史料において最も注目すべき点 は、屋敷地一筆ごとに振られている地番の存在である（図 2 )。これ は郭内・郭外（甲府城内堀を境にした区分）の別に通し番号のかた ちで振られているもので、以下に示す史料がその発生事情を示唆し ている(括弧内およびルビ筆者、以下同様)。

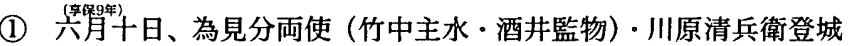
相済、扔家中諸屋敷曲輪の内百四拾八番・曲輪外式百式拾六番、

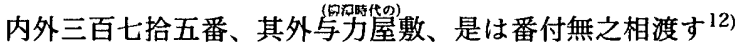

これは幕去の編筑史料の一部ではあるが、柳澤家から幕府への甲 府城引渡しの経緯を記したもので、ここから城とともに武家屋敷の 引渡しが行われた際に「番付」が振られたであろうことが推察され る $^{13)}$ 。これは引渡しの合理化のための処理であったと考えられ、『甲 府勤番日記』の記載から拝領時点での状況を見ても、郭内に拝領し た勤番士は110人 (149筆中 115 筆)、郭外は88人 (226筆中96筆) ${ }^{14)}$ 、 不明が 2 人となっており、原則として引継ぎ前の屋敷地の単位が勤 番士への屋敷地の割り当ての単位となっていたことが分かる ${ }^{15)}$ 。翌 年拝領者は若干変更されたが、その後も番付は原則として与力以上 の武家屋敷の表示方法として使用されつづけるのである ${ }^{16)}$ 。

しかしこのような地番のシステムは一般の城下町の武家地におい
ては穎例のないものである。なぜならそうしたシステムは屋敷地の 変動によって容易に破綻をきたしてしまうからだ。にもかかわらず 甲府においてそれが可能であったのは、当初の甲府勤番制の有して いた特質ゆえに他ならない。ここでは次の 2 点を指摘しておきたい。 （i）勤番士人数の恒常性：先述のように設立当初の勤番士数は200 名とされており、それは明白な計画性を認めうる数だと言える。そ の後も天明末年までの65年間における改易以外での転出は僅か 6 名に過ぎず、また江戸からの新規転入も 9 名（うち 1 名は甲府入り

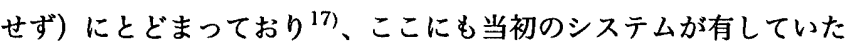
佰常性への志向を見ることができるだろう。

(ii) 屋敷地の恒常性 : 甲府への引越し後、翌享保10年 7 月までに居 住条件の悪い屋敷地を拝領した勤番士に対する屋敷替の措置がなさ れたものの ${ }^{18)}$ 、同年11月に出された掟書では「役屋敷之儀者格別、 其外向後屋敷替申付間敷候」19) との通達が下されており、原則とし て以後は屋敷替を慗止する方針となっていたようだ。なお、この掟 はその後結局有名無実化するが20)、それでも原則論としてこのよう な規定がなされていたことは注目に值しよう。

このような特質は多分に江戸的な論理の発現であった。幕府の側 にとっても、勤番士の側にとっても、甲府勤番はあくまで派遗され た「幕府の旗本」であり、建前上彼らの屋敷も「江戸の飛び地」と して把握されるものでなければならなかったのである。それは次の 史料からも顕著に窥うことができる。

(2) 享保甲辰の秋、勤番の面々江府に於て、甲陽侍屋敷を洋領仰付 らる>旨、両支配、番附・坪数書付を以て申渡さる。然る処に 引越して見るに、広狭相違し、家作破壊なる処あり。是分は翌 年願奉りて、屋敷替仰付らる>21)

ここで注目されるのは屋敷地の拝領が江戸において行われ、しか もそれが甲府の屋敷地の実情とは無関係に行われた、という点であ る。まさに番付とは江戸の視点からの機械的な屋敷配分の象徵に他 ならなかったのである22)。

では、このような空間のあり方は甲府勤番の当初の設立意図とど う関連していたのだろうか。村上直氏が指摘しているように、「主と して甲府城を守護し、城米および弓矢鉄砲などの武具を準備し、府 中の政務をおこなうこと」 ${ }^{23)}$ が甲府勤番の第一の目的であったこと は言うまでもない。それは「天領拡充と幕府権力の浸透をはかる幕 府政治の方向を顕著に示した政策」 ${ }^{24)}$ の表れであったのである。し かし甲府勤番は必ずしもそのような積極的な意味合いのみを有して いたのではなく、一方では寺田登氏が指摘するように、寄合・小普

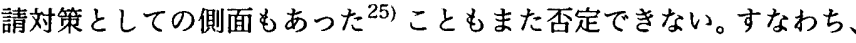
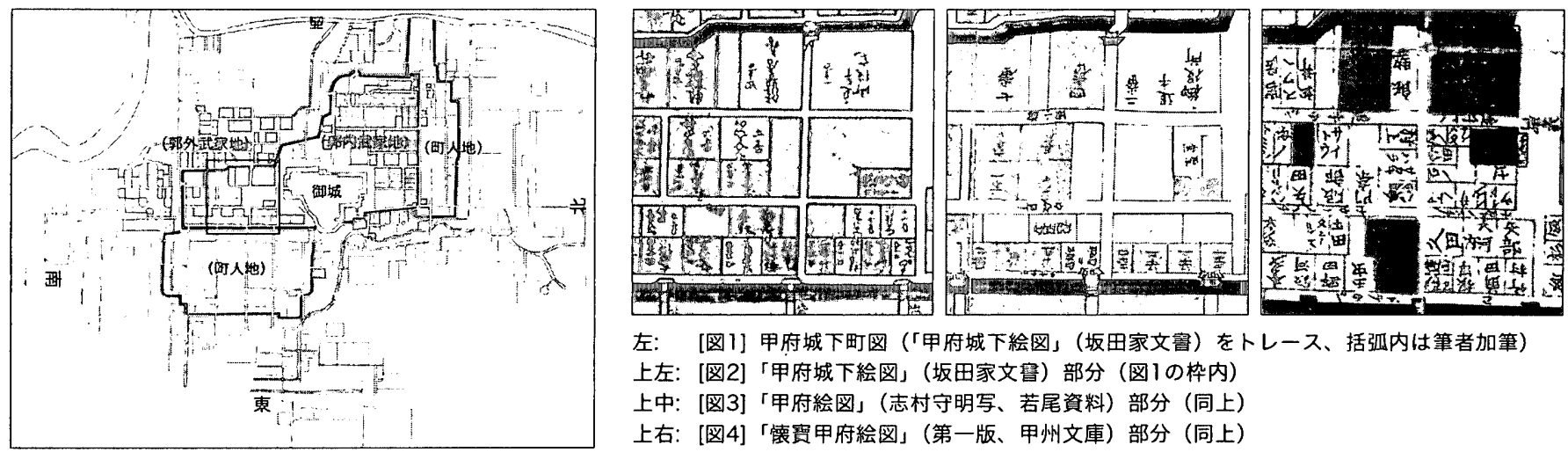

左：［図1]甲府城下町図（「甲府城下絵図」(坂田家文罾）をトレース、括弧内は筆者加筆）

上左：[図2]「甲府城下絵図」（坂田家文寒）部分（図1の枠内）

上中: [图3]「甲府絵図」(志村守明写、若尾資料) 部分（同上）

上右：[図4]「瀆寐甲府絵図、（第一版、甲州文庫）部分（同上） 
享保期のあたりから、多数化する非職の幕臣団をいかに管理してい くかということが幕政上の大きな課題として浮上してきており ${ }^{26)}$ 、 甲付勤番は彼ら午員の活用先としても意図されていたというのであ る。実際、平澤勘蔵氏の分析によれば、勤番士となった小普請200 名のうちそれまで役職の経験が皆無であったものが159名を占めて いたといい27)、その意味で甲府勤番の設置は、幕府側にとっては午 員の整理、小普請の側にとっては役職への登用という、両者の思惑 を合致させる政策だったと言えるのである。

このように甲府勤番の設置は幕府の天領政策のもつ $2 つ の$ 側面、 すなわち全国支配を更に強化しようとする積極的側面と、幕政の諸 矛盾を処理するために利用しようとする消極的側面の双方を浮かび 上がらせるものであった。甲府という場所の論理を考慮せずに機械 的な番号で屋敷地を割り付けていくという方法は、まさにそのよう な幕府＝江戸の論理による勤番士の「植え付け」の表れにほかなら なかったのである。

\section{3. 甲府勝手小普請制と武家屋敷}

「甲府城下絵図」以降の甲府を描いた絵図で次に古いものとして 挙げられるのは若尾資料の志村守明写「甲府絵図」である。これに は「弘化二乙巳五月吉辰写之」との記載があり、原図は記載事項か ら判断して寛政 7 (1795) 享和元(1801)年のものと推定されるが 28)、この絵図の特徵的な点は、ただ番付のみが情報として記されて いるという点である (図 3 )。人名はここでは省略されているが、逆 に言えばそれは当初の番付と拝領者との 1 対 1 の対応関係がこの時 点でもなお全体的に見て有効性を失っていなかったことを示すもの と考えられよう。

しかし一方で、制度面においても空間面においても当初のシステ ムに変容の兆しが現れはじめたのもこの頃からであった。中でも大 きな出来事と考えられるのが寛政元(1789)年の甲府勝手小普請の新 設であろう。これは寛政改革の一政策で、いわば「甲府詰の小普請 組」29)として新設されたもので、管見の限りでは同年 9 月27日に 小普請組酒井因幡守支配の森川市右衛門に発令されたのが初例であ る ${ }^{30)}$ 。そしてこれを皮切りに寛政期だけでも33名、その後も不断に 派遣が続くことになる。その性格は通常、不良幕臣の事実上の配流 として理解されており、またその理解は誤りとは言えないが、ただ その側面のみに目を奪われてしまうと本質を見失うことになろう。 すなわち、江戸からの転入者が増加している一方で、この寛政期に は甲府からの転出も盛んに行われているのである。特に寛政 2 年 9 月の駿府勤番制開始時には甲府から20名の勤番士が転出している
し31)、また江戸への転出者も寛政期だけで19名を数えている ${ }^{32) 。 つ ~}$ まり当時の旗本植猗九八郎が「甲州勤番の儀、只今迄不行跡の者を 被遣、其子孫に至り行状よき者を八間々御当地へ被召帰候」 ${ }^{33)}$ と述 べているように、甲府勝手小普請の流入は「行状よき」勤番士の江 戸転出と裏表であったのである。また、甲府入りした小普請にして も、御目見以上であればその後の勤番士への昇格 ${ }^{34)}$ 、また御目見以

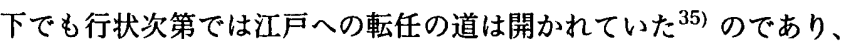
従ってこの甲府勝手小普請の創設は、一方的な配流というょりも綱 紀肃正を意図した幕臣団の流動化策と理解したほうが正確であろう。 網紀肃正という点では江戸の側も甲府の側も利害が一致するが、 特に後者にとっては、勤番士の士気低下は甲府勤番制そのものの基 盤をゆるがしかねず、勤番士の流動化はそのためにも避けられない 道であったと考えられる。しかし逆説的ではあるが、このことこそ が先に述べた勤番制当初の空間的な規定性を変容させていく最大の 要因となるのである。

一例として図 5 に示した「郭外代官町屋敷割図」を検討しよう。 これは番付で言えば剠外168番から171番までの 4 筆の状況を描い たもので、上段にそれぞれの間口と裏行、坪数が記されている。と ころが下段を見ると、黒で描かれた番付の区劃とは別に、朱書によ り屋敷拝領の状況が描かれていることに気付く。これを読み取って 情報を整理したものが図 6 である。ここには 5 名の拝領者が記され ているが、彼らはともに寛政 5 (1793)年 3 月に勝手小普請を命じら れて甲府入りした伊賀同心で、禄高は塩沢・柚原木・富田が30俵 2 人扶持、磯崎・鉿木が 30 俵 3 人扶持と、ほほフラットであった ${ }^{36)}$ 。 ここで最も注目されることは、彼ら 5 名の屋敷拝領の単位が番付の 区劃とはほとんど無関係であるという点である。このことは甲府勤 番制開始当初と甲府勝手小普請制開始時期の屋敷洋領状況の差を端 的に示しているように思われる。つまりそれは、全てが明屋敷とな ったところに屋敷を割り付けていける状況と、その時点で明いてい る屋敷地のみで割付を行わなければならない状況との差異である。 高相応の屋敷を供給するという大前提のもとでは番付区劃の原則は 二義的とならざるを得ず、こうして当初の番付にもとづく空間の秩 序にも次第に綻びが生じてくるのである。

\section{4. 空間秩序の変容}

では、19世紀以降の変容について見ていくことにしょう。使用す る史料は甲州文庫所蔵の「懐寶甲府絵図」である。これは甲府にお いて広く頒布を目的として出版された唯一の木版図で、嘉永二年己 酉七月上梓 甲府魚町四丁目擁萬堂村田屋孝太郎誌」と記されてい

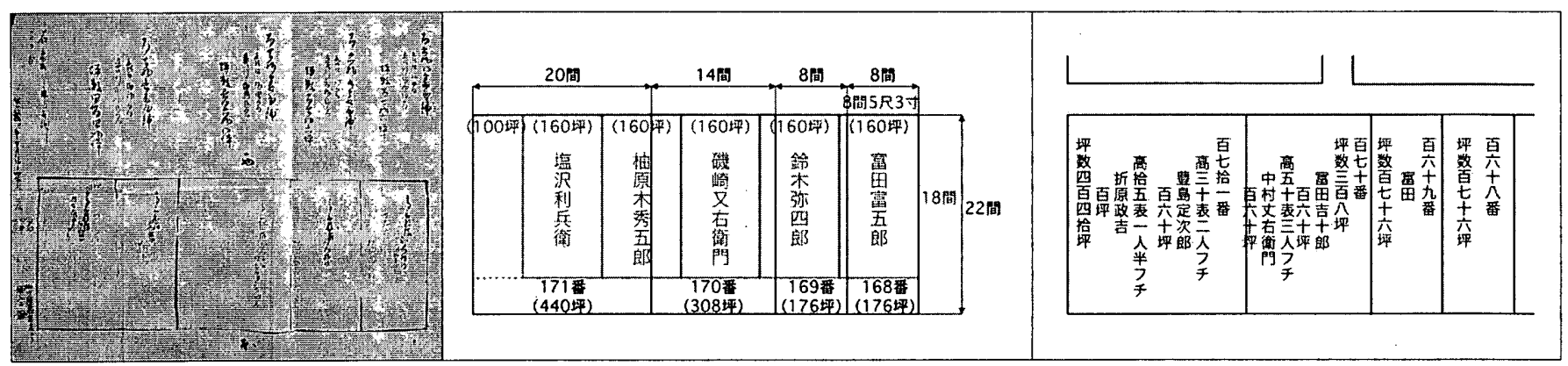

左: [図5] 郭外代官町屋敷割図（寛政5(1793)年、赤岡重樹旧蔵資料、山梨県立図書館所蔵）

中: [図6] 郭外168番〜171番における屋敷地配分図（図5をもとに作成、グレー部分が原図朱書の記載にかかわるもの）

右：[図7] (参考) '甲府郭内外番附屋敷仮絵図帳」(天保期か。赤岡重樹旧蔵資料、山梨県立図畫館所蔵）における168〜171番 
る。但しこれには初版と二版の二種類があり、記載人名を検討する と後者は実際には慶應元(1865)年以降の甲府を描いたものであるこ とが分かり、この点注意を要する ${ }^{37)}$ 。本稿では初版を主として用い る(以下「懐審初版」と呼ぶ)。

さて、絵図の記載について最初に気付く点は、武家屋敷の表記に おいて番付が姿を消しているということである。のみならず、屋敷 地の区劃も当初のものと大きく異なるものとなっている(図4参照)。 そこで「甲官便覧」38)などの史料も参照しつつ、絵図に記載されて いる人名を検討すると、大きく次の 2 点を指摘することができる。

\section{a) 郭外から郭内への移動}

一つは、当初からの勤番士の郭外から郭内への移動である。「甲 府城下絵図」以降「懐璸初版」に至るまでの武家屋敷の動向につい ては、志村守明写「甲府絵図」のほか、「文化十一年甲府城職員名鑑」 39)、「甲拊郭内外番附屋敷仮絵図帳」(以下「仮絵図帳」とする) ${ }^{40)}$ 、 弘化 2 年「甲官便覧」などによりある程度の追跡が可能である。こ れらをもとに旧郭外居住者の郭内への移動状況についてまとめたの が表 1 である。これは逆に郭内から郭外へと移動した事例（6例） の 5 倍以上にあたり、郭内への求心的移動の傾向は顕著と言える。 このような移動は、早い事例では享保・寛延期に既に見られるもの の、大半は寛政期以降においてであり、そこには先述したような勤 番士の流動化が関わっていると考えられる。実際、江戸或いは駿府 への転任によって明屋敷が発生したところに郭外から勤番士が移転 した事例は表 1 においても多く確認できる。

更に注目すべき点は、移転前と移転後の屋敷が多くの場合同規模 で、中には全く同じ坪数である事例も見られるという点である。例 えば(ソ)の桜井は当初郭外佐渡町218番屋敷 (442坪) を拝領してい たが、その後大橋万吉の駿府転任（寛政2年）に伴い明いた屋敷（郭 内先手小路71番)に移ることになるが、この屋敷は489坪 (『甲府勤
番日記』では484坪）の規模があったにもかかわらず、桜井が拝領 したのはこのうちの442坪で、残り41坪は名目上借地としているの

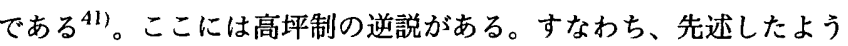
な勤番士の「植え付け」としての視点からすれば、屋敷地の配分は 高坪制の適用（家禄高に応じた規模の屋敷を与えること）こそが第 一義であった。従ってこの価值体系においては郭外442坪の屋敷も 郭内442坪の屋敷も同格ということになり、逆にそのことが、郭外 居住の勤番士が「同格」の（一方で甲府という場所の論理において は格の高い ${ }^{42)}$ ) 郭内屋敷に移動することの正当性を与えることとな ってしまうのである ${ }^{43)}$ 。甲府の場所性を無視した原則が却って甲府 における同心円的なヒエラルキーを浮き彫りにする。表 1 に示した 勤番士の移動はその顕著な例だと言えるだろう。

b) 屋敷地の細分化

二点目として挙げられるのは屋敷地の細分化である。甲府に流入 する勝手小普請の増加は、特に規模の大きい屋敷地の細分化をもた らした。例えば郭内追手小路 11 番屋敷は2,501坪の規模を有したも のの長らく明屋敷であったが、「懐寶初版」を見ると 5 分割されてい る。そこで記載人名を子細に検討すると、4名が天保12(1841)年か ら14年にかけて勝手小普請として甲府入りした武士であったこと が分かり、この時期に細分化がなされたと推察される。また、「䁲寶 初版」では12筆に分割されている郭内森下小路46番屋敷は本来全体 4,092坪で一筆であり、ここも長らく明屋敷であったが、天保期あ たりから細分化が始まったようである。「仮絵図帳」には46番を描 いた図が 2 種類あるが、このうち天保 4 年以降に描かれたとみられ る図には 3 名、天保 12 年以降と見られる図には7名が見られ、この 敷地が新規勝手小普請への屋敷地として供されたことが窥えよう。

上に挙げた例に限らず、甲府の武家屋敷の細分化にとって天保期 は一つの㔅期であった。特に天保改革期にあたる天保 12 年 5 月から

[表1]旧郭外居住者の郭内への移動（享保10年8月以降）

\begin{tabular}{|c|c|c|c|c|c|c|c|}
\hline 記号 & 初代勤番名 & 郭外時代の屋敷 & 郭内移転先 & 移転時期 & 移䎐先の前拝領者 & 厂樯留初版」 & 備考 \\
\hline 1 & 小笠原伊左衛門 & 166番322坪 & 中殿町18番 & 享保19年 & 深谷左源太・享保19年転任 & 土手小路 & 組頭就任により引替 \\
\hline & 佐々木数馬 & 144番384坪 & 攜小路61 番うち384坪 & 寛延4年 & 原田藤十郎 - 享保20年転任 & & 明和8年遠島 \\
\hline 八 & 鈴木八十郎 & 2番750坪 & 鹤小路56番527坪 & 延享4年 & 小倉安右衛門·相対替 & 土手小路 & 組頭就任により相対替 \\
\hline$\equiv$ & 川辺四郎左衛門 & 222番400坪 & 厩跡315坪 & 宝曆4年以前 & 不明 & +2 & のち㢦小路、天保9年転任 \\
\hline 木 & 佐久間五郎右衛門 & $26 \cdot 27$ 番 & 䟽跡315坪 & 宝棟4年 & 川辺吉古衛門·先手小路へ & & 天保以前に転任か \\
\hline 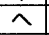 & 中村宇之助 & $24 \cdot 25$ 番 & 先手小路79番うち340坪 & 宝暦6年 & 明屋敷 & 先手小路 & ほか借地 \\
\hline 下 & 野田一学 & 220番 & 偎先手小路121番310坪 & 宝曆6年 & 大久保内蔵助・享保19年転任 & 同左 & \\
\hline 千 & 恒岡新八郎 & 157番352坪 & 新先手小路138番 & 宝暦13年 & 明屋敷 & 裳先手小路 & \\
\hline リ & 福井七郎右衛門 & 119番348坪 & 中殿町 & 寛政〜文化か & 不明 & & 文化6年転任 \\
\hline 7 & 森長四郎 & 154番330坪 & 山田町阿前 & 寛政～文化か & 不明 & & 天保以前に転任か \\
\hline ル & 斎田伝八郎 & 153 番 330坪 & 先手小路 & 實政～文化 & 不明 & 中殿町 & \\
\hline 7 & 小幡数馬 & 77番507坪 & 中殿町26番507坪 & 寛政～文化 & 䎿訪吉之丞・寛政2年転任 & 廐跡 & \\
\hline 7 & 宇佐美春沢 & 117 番348(368?)坪 & 先手小路80番 252 坪 +81 番う5116坪 & 寛政～文化 & 滝野元長・寛政9年転任 & 同左 & ほか借地 \\
\hline 力 & 洅原兵吉 & 137番337坪 & 桜小路58番うち300坪か & 寛政～文化 & 依田源太郎・享保20年追放 & 同左 & \\
\hline$\exists$ & 庵原勘右衛門 & 147 番330坪 & 森下小路52番うち330坪 & 寛政～文化 & 小栗庄右衛門・葸政2年転任 & 筒左 & ほか借地 \\
\hline 夕 & 芦屋伝右衙門 & $197 \cdot 198$ 番360坪 & 先手小路98番362坪 & 寬政～文化 & 明屋敷か & 同左 & \\
\hline$L$ & 佐々木庄助 & 56番360坪 & 厩跡 & 寛政〜文化 & 明屋敷 & 嘅跡 & \\
\hline ソ & 桜井宇之助 & 218番442坪 & 先手小路71番うち442坪 & 寛政～文化 & 大橋万吉・寛政2年転任 & & ほか借地、天保9年転任 \\
\hline ツ & 佐々木隼人 & 159番396坪 & 厩跡 & 寛政〜文化 & 明屋敷 & & 天保9年転任 \\
\hline & 山田四郎五郎 & 1 番380坪 & 先手小路76番うち380坪 & 寛政～文化 & 野田源五郎・寛政8年転任 & & \\
\hline$\overline{5}$ & 湯川百助 & 125 番495坪 & 土手小路29番うち400坪 & 享和か & 大河内・中殿町へ & & 嘪永2年転任 \\
\hline$\Delta$ & 本間伝左衛門 & 206番321坪 & 先手小路91番510坪 & 文化頃 & 中村·中殿町へ? & 同左 & ほか借地、弘化2年転任 \\
\hline ウ & 芥川弥三郎 & 17 番300坪 & 蔓先手小路114番297坪 & 文化～天保 & 石川五郎右衛門·寛政 11年転任 & 先手小路 & \\
\hline 芰 & 伴孫太郎 & 18 番306坪 & 桜小路63番560坪 & 文化～天保 & 山本与次左衛門 $\cdot$ 相対替 & 同左 & 組頭就任により相対替か \\
\hline 广 & 根岸市十郎 & 19 番 300 坪 & 土手小路33番うち330坪 & 文化～天保 & 浦・郭内14番へ & 同左 & \\
\hline 才 & 朝比奈新之丞 & 21番300坪 & 新先手小路144番うち288坪 & 文化～天保 & 浅羽文右衛門 - 寛政2年転任 & 襄先手小路 & \\
\hline ク & 矢部嘉七郎 & 145 番330坪 & 中殿町 16番 & 文化〜天保 & 小川数馬・寞延2年屋敷引払 & 同左 & \\
\hline ヤ & 今村左原太 & $106 \cdot 108$ 番430坪 & 森下小路46番うち470坪 & 文化～天保 & 明屋敷 & 記载なし & 両r便覽」では先手小路 \\
\hline$\nabla$ & 東僮弥十郎 & 110 番399坪 & 土手小路31番うち400坪 & 文化～天保 & 户田淯九郎・寛政2年転任 & 記载なし & 峏r便覧」では霞小路 \\
\hline$ケ$ & 本多源八郎 & 188 番390坪 & 土手小路38番 & 天保頃 & 佐々井金十郎借地 & 同左 & \\
\hline 7 & 葉山三十郎 & 211番316坪 & 中殿町 & 天保～弘化 & 不明 & 記戴なし & \\
\hline ב & 玉虫佐兵衛 & 納戸小路 & 土手小路35番 & 弘化〜嘉永 & 柴田・追手小路へ? & 同左 & \\
\hline$I$ & 権太半藏 & 204番380坪 & 土手小路39番 & 㚳永 & 上田弾正借地・嘉永2年転任 & 同左 & \\
\hline
\end{tabular}


同14年閏 9 月にかけてのおよそ 2 年半には実に 64 名 (うち御目見以 上52名）にものぼ幕臣が勝手小普請として甲府に送られたのであ って、このことが屋敷地の細分化を急激に進める大きな要因となっ たものと思われる。結果、屋敷地の単位をもはや示さなくなった「番 付」は実質的に意味を喪失していくことになる。

ここで注意すべきは、この天保改革期の勝手小普請の流入と寛政 期のそれとの最大の相違点、すなわちこの期間の江戸転任者がわず か 1 名に過ぎなかったという点である。このことは甲府が江戸にと つて「不良」幕臣の厄介払いの対象としか見なされなくなっている 証拠に他ならず、従って「番付」の無意味化とは、屋敷地の細分化 がもたらしたのみならず、幕府が甲府の武家屋敷を合理的に把握す るということそのものが無意味化したことともパラレルであったと 言えるのではないか。そして、これと表裏一体のかたちで浮かび上 がってくるのは甲府自身の有する論理、すなわち先述したような武 家屋敷のヒエラルキーを伴う場所の論理であり、それは時に「拝領」 の枠すらつき崩していくことになる。事例としてここでは『萬代日 記』の享和 $3(1803)$ 年の記事に以下のようなくだりがあることに注 目したい。

(3) 一、四月八日夜、大手東湯川百助殿長屋やけ申候。

一、同十一日昼八ッ時、同所鈴木鉄吉殿長屋やけ申候。 是八大河内彦十郎殿表向名前之由二候。(後略) ${ }^{44)}$

ここでいう大河内彦十郎とは享保 9 年に郭内土手小路（大手東小 路）29番屋敷を拝領した大河内十太夫の子孫である。ところが「仮 絵図帳」では29番に湯川林之助（ほかに曲㴊団助借地）、30番に鉿 木八郎右衛門の名前が見え、大河内は郭内 17 番に移っていることが 分かる。この17番屋敷を拝領していた藤沢孫左衛門、30番屋敷を拝 領していた間宮十左衛門はともに享和元年に転任となっており、移 動はその後まもなく行なわれたと考えられるが、ここで注目すべき なのは上揭史料の「是八大河内彦十郎殿表向名前」という表現であ る。これは屋敷地において名義の保持者と実際の居住者とが相違す る場合があったことを示すに他ならず、ここでは大河内と鈴木 ${ }^{45)}$ との間に屋敷の賃貸関係が成立していたことが窥えよう。実際、「仮 絵図帳」には择領地と空間的に離れた（つまり居屋敷の拡大目的と は考えにくい)「借地」の記載が散見され、これも拝領地以外への居 住の広まりを予感させる。ここに見られる勤番士の動きはもはや江 戸二幕府による屋敷地統制とは異なる、まさに甲府という都市自身 のもつ文脈に応じたものであったと言えるのではないか。

\section{5. 結びにかえて}

以上、直轄化後の甲府における武家屋敷の空間秩序を、「番付」に 着目して考察してきた。しかし、そこで見てきたような「直轄都市」 としての論理に対する城下町甲府自身の論理の咥頭は、必ずしも本 稿で述べてきたような武家の居住の問題に限られたことではなかっ た。以下ではこの問題について、町方との関係をも視野に入れつつ 考察し、結びにかえたい。

先述したように、直轄都市甲府は幕府の天領支配の強化および非 職の幕臣団対策という2 点を目的としたもので、何よりもまず幕府 のために存在したものであった。そこでは都市の支配層に求められ るはずの、都市民の保護者としての役割はあくまで二義的なものに 過ぎず、安藤正人氏が指摘するように、直轄化後の都市政策は「都
市維持のための諸負担を町方により多く転嫁する方向」46) へと進ん でいくのである。このことは町方人口においても如実にあらわれて おり、柳澤時代の享保 $5(1720)$ 年における13,621人が19世紀初頭に は1万人を割るまでに落ち込むこととなる47)。

武家屋敷のあり方でも見たように、甲府という都市自身の論理を 無視したまま都市を運営していくことは現実には不可能であった。 それゆえ甲府における都市政策も何らかの方向転換を余儀なくされ たはずだが、ここではその一端を徽典館という教育施設を事例とし て窥ってみたい。

徽典館は寛政 $7(1795) \sim 10$ 年頃に当時の甲府勤番支配が勝手小 普請富田富五郎の学才を評価し、役屋敷に仮の学問所を開いたこと に端を発し ${ }^{48)}$ 、文化元(1804)年には校舎が新筑され ${ }^{49}$ 、更に天保 14(1843)年には規模を拡大して江戸より教授が派遗されることと なった ${ }^{50)}$ ここはは旧門弟の内山慨が称しているように、駿府の明新 館とともに江戸昌平黌の「支校」としての性格をもつ施設であった ようだ51)。ただ、『甲斐茜手振』における「天保十三寅年、酒井房 州・浅野中務鎮台の頃、駿府御目付戸田寛十郎と相謀りて官へ告し、 諸事御改革の折柄に付猶又学校再建の義被申」 ${ }^{52)}$ との記述は、これ ら一連の動きがむしろ甲府側から推進されたものであることを示唆 している。ここには直轄都市の論理の転換がある。つまり、本来直 轄都市とは他ならず江戸幕府のために存在するはずのものであった のが、ここでは「甲府の武士」の教育のために直轄都市としての立 場が逆に利用されているのである。

更に町方に目を転じれば、この徽典館が「農・工・商中有志者」 に対しても開放されていたこと沾)、またこの施設が医学所も併設し ており、甲府の都市民に対する医療行為も行なっていたこと ${ }^{54)} も$ 注 目される。これは一面では「知」の独占とその分与を通じた民臬支 配とも解せるが、しかしそれ以上に、ここで提供された教育・医療 によって甲府の都市民が広く恩恵を受けたであろうことは否定でき ない。このことは、甲府の都市政策が、都市維持のための諸負担を できるだけ町方の側に転嫁するような、当初の意味での「直轄都市 の論理」とは明らかに異なる方向性をとりはじめていることの証し と言えるのではないだろうか。

武家地の例、また徽典館の例で見たように、19世紀以降の江戸と 甲府の関係は、直轄化当初のような「中央政府による地方支配」と いう単純な図式では解けない。そこでは幕府の論理のみならず、甲 府在住の武士、或いは町方など、複数の集団の論理が、時には互い の論理を逆に利用しながら複雑に絡み合っているのである。本稿に おける考察は、その関係性を空間の面から解きほぐすための一つの 試みである。

註

1)例えば甲府の都市空間についての先行研究には饭沼賢司「戦国湖の都市 “甲府” (『甲付市史研究』第 2号、1985年11月)、中沢信吉「甲斐俯中概

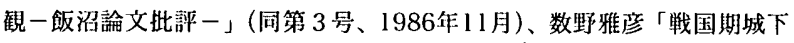
町甲府の景觀復元」(『山梨の考古学論集』III、1989年)、伊藤裕久「近

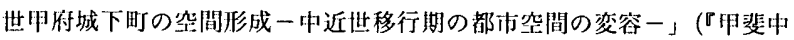
世史と仏教美術及、名藷出版、1994年、のち伊藤『近世都市空間の原景』、 中从公論美術出版、2003年に侢録) などがあるが、その手法は即往研究 の枠に甲府を適用したに過ぎい（数野氏による飯诏論文批判）か、ま

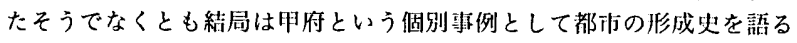
にとどまっているように思われる。 
2)直軦化以前の甲府は城主の交替が頻繁であった。すなわち、渞長 8(1603) 〜 12年が徳川義直、元和 2(1616)年までが城番制、筧永 9 (1632)年まで が徳川忠長、寛文元(1661)年までが城番制、宝永元(1704)年までが甲付 徳川家、そして享保 9 (1724)年までが柳澤家である。もつとも、城主と して実際に甲府入りしたのは最後の甲府城主、柳澤吉里のみであった。

3) ここで言う「面輁战下町」とは、(1)城部が直轄化後も都市の軍事的・政 治的中心施設として機能していること、(2)町方支配の組織が独自におか れていること、を条件として想定している。大坂や駿府などもこれに相 当すると思われるが、今後の課題である。

4)『德川實紀」第 8 篇("改訂增補国史大系』第45巻、吉川弘文館、1933 年)、関連頁は pp.330-331、p.341、p.345。

5）なお、甲斐国天領のうち村方については代官支配のもとにおかれたため、 甲府勤番は甲府城の防衛と甲拊町方の民政を尃ら担当することとなった。

6) 江戸東京博物館所藏甲府勤番別所文書、屾梨県史」史料編 8 近世 1 領 主 (山梨県、1998年) 所収。旧甲拊勤番の別所家に伝来する享保 9 (1724) 年〜安永 $9(1780)$ 年までの甲府勤番に関する記録である。ここに設立当 初の甲苻勤番全貝のリストが収録されている。石高のみならず屋敷地、 その後の動向についても記載され、情報量は豊富である。類似史料とし て『寒見寒話』(『甲斐丵書』第6巻、第一書房、1974年 所収)、「甲府在 番総人数高附帳」(斎藤典男「成立期甲府勤番士の知行高について」(『甲 斐史学』第22号、1967年 7月）において翻刻）などがあり照合可能。

7) 前揭『毫見寒話』に・石御役屋敷、最初は择領屋敷と成て、曲淵野州・ 有馬羽州の如き、江戸表の拝領地差上罷越、御役替御免にて㷌府の節、 空地に材木等被下事なし、然るに宮畸若狭守、当役を蒙り颜候に付、夫 より已来御役屋敖と成る」(p.32) とある。

8）例えば『甲府勤番日記』にも「出羽守・能登守支配之者屋敷之儀、彼地 城下屋較高相応二家作共二可被下候。但当地之屋敷者家作共二可差上候」 (p.973)と見える。

9) 但し甲府勤番艾配は例外で、一般に数年の任期で江戸に転任している。

10）坂田家文書、『甲府市史」史料編第 2 巻 近世 I (甲府市、1987年) 所収。

11）享保20年に追放となった勤番士 6 名の屋敖地が「明地」とされているこ と、また甲府代官所の人名が山田治右衛門（享保19〜元文 4 年在職）と なっていることから判断した。

12)『甲府御城付』(『甲府市史』史料編第 2 巻近世 I 所収)、p.229。これ は安政 $6(1859)$ 年以降）編算の甲府城関連の記録集である。勤番支配を はじめとする要職者の一覧、また勤番士・勝手小普請の異動の記録など、 甲府における武士の状況を知る上で久かせない史料と票える。

13)これは『裏見寒話」における「甲府士屋䑤軒数 御郭内百四拾九軒 御 郭外三百式拾五軒」(p.21) という記載とも対応するものと考えられる。

14）ほか番付をもつ与力屋敷19筆（あと1 騎分は不明）が郭外に確認できる。

15）なお、この際発生した明屋數については享保10年に厸下げが行われてい る(山梨県立図著館所藏「御用留帳」)。

16) まれに番付のない屋㩆地も存在したが、絵図などでは「番外」として見 える。なお、同心以下の居住する組屋敷には番付はふられていない。

17）前揭『甲府御城付』による。

18）前揭『甲府勤番日記』享保10年の記事に「今年郭外洋領屋敷、場所・家 作悪敂住居難儀面々願替申上、七月御引替済」(p.1017) とある。

19）『甲陽楖秘録』(『甲斐叢書』第 3 巻、第一書房、1974年 所収)、p.36。

20）例えば前揭『甲府勤番日記』を見ても、早くも寛延 4 (1751)年に佐々木 孫市が屋敷替を行っている旨の記載が見える(p.981)。

21）前揭『変見寒話小,p.26。

22)このことは番付の割付方法にも䫓著に表れている。すなわち、郭内・郭 外とも、通りに沿って番号が順々にふられたものに過ぎず、城との距蓶 あるいは屋嫩規模との相関は全く見出せないと言ってよい。

23）村上直「甲府勤番支配の成立」(『甲斐史学」特集号、1965年10月)、p.13!。

24) 同上, p.129。

25) 寺田登「幕政改革と奇合・小普請対策について」(『国史談話会雑誌』第 23号、1982年 2月)。

26) 実際、徳川吉宗の将軍就任時にも200名を超える紀州藩士が幕臣化して いたのであり、筆者がかつて指摘したように、甲苻勤番設置による明屋 敷の発生が彼ら新嫢幕臣への屋敷地配分に靧献したことも併せて考える と興味深い。拙稿「紀州落士の幕臣化に伴う江戸屋教獲得動向」(『日本 建築学会計画系論文集』第561号、2002年11月）参照。

27）平澤勘蔵「甲府勤番支配の成立に関する一考察一主として勤番士の閲 歴・系譛を中心に一」(『法政史学』第28号、1976年 3 月)。

28) 判断材料としては追手門前に「聖堂」が描かれていること(寬政 7 〜 10 作頃設立の学問所に関係か)、また後に薬園がつくられる敬地がまだ勤番 士居住地（牧野氏の宅地、享和元年に江戸転任）となっていることが举 げられる。なおこの点はこれまで論点として提示されていない。

29）寺田登「甲府勝手小普請について」(『国吢談話会雑誌』第 19 号、1978
年 3 月)、p.26。

30) 前揭「甲府御城付』、p.316。なお同『甲府市史』では「安政元酉年」と 記載されているが、これは翻刻の誤りで宽政元年が正しい。

31) その成立の経緯については寺田登「駿府勤番について」(『地方史静成』 第 8 号、1978年11月）を参照のこと。

32）前揭『甲府御城付』による。

33)「值㱦九八郎上書写」(享和元年、『甲府市史』史料編第 3 巻 近世 11 、 pp.111-118)。

34）例えば寛政期に甲府勝手小普請入りした33名のうち御目見以上は10名 であったが、うちその後の動向不明の1名を除く全貝が遅くとも弘化 2 年までに勤番入りを果たしていることが確認される。弘化 2 年「甲官便 覽,(頼生文庫、山梨県立図書館所藏) 参照。

35）幕末期のものではあるが、甲府勝手小普請江戸表御奉公之儀二付奉願候 書付」(曼愿 3 年、内閣文庫所藏江戸城多聞櫓文書) などの史料からは、 行状のよい勝手小普請が甲府勤番支配により江戸㷌逥の推蔍対象となっ ていたことが窥える。この史料で推蔦されている内山安之丞は僅か高 15 俵 1 人半扶持であった。

36) 前揭『甲付御城付』、p.317。

37) それにもかかわらず多くの先行研究は二版のものを嘉永甲府図として紹 介している。初版と二版とでは記載人名の相違も多く、このことに何ら 注意が厸われないまま使用されてきたことは、従来の甲府都市史の研究 における重大な過失と言わねばならないだろう。

38）本稿では頼生文庫本と若尾資料本を用いた。前者は「弘化二乙巳年改 甲 府魚町四丁目 村田屋孝太郎板」との記載がある小型の分限帳で、勤番 士・腾手小普請らの姓名と石高、居住地（勤番士のみ）が記される。後 者には年月の記載が見えないが、史料に見える小笠原長門守と小田切土 佐守の両名が甲府勤番支配であるのは安政 $3(1856)$ 年 4 月 25 日から翌 年 3 月13日までに限られ、この一年間に絞り込める。記載事項は基本的 に前者と同じ。以下、前者を「弘化便覽」後者を「安政便覧」とする。

39）赤网重樹旧藏史料、山梨県立図書館所蔵。赤岡重樹氏は戦前の郷土史家 で、彼による写本が残る。冒頭に「文化十一甲戊之春三月記之」とあり、 記される勤番支配名はこの時期と矛盾しない。しかし仮役として挙げら れている勤番士名から判断すると、この名鑑は当初文化 2 (1805) 3 年 につくられ、同11年時点で部分的に訂证が加えられたものと見るべきだ ろう。本稿ではあくまで移転時期推湖の参考程度に使用するにとどめる。

40）赤阅重樹旧藏資料、山梨県立図書館所蔵。大正13年に廣瀨廣一氏による 写本を昭和 16年に赤阙氏が写したもの。「此艮文政中甲府城附同心御普 請方付中川為徳所写、蓋府庫所藏者也」とあるか、、記載人名加らすると 天保初期、また「貼紙」は天保後期のものと見られる。同一敫地を描き、 かつ記載内容が異なる図もあることから図の作成年代には数年のずれが あると考えられる。原本の所在が不明なことが惜しまれる史料で、それ ゆえ無批判に用いることは危険だが、武家屋敷の土地所有の状況を最も 詳しく示してくれる史料であることから、嫃重を期した上で使用したい。

41) 前揭「仮絵図帳」。

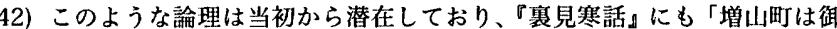
战へ拾四・五町を隔る。夫故当所にて据領の勤士は(享保10年に)悉く郭 内(ママ)納戸小路へ移る」(pp.26-27) との一節が見える。

43）なお、これらの移動が甲付勤番士自身の意向を反映したものであること は、『甲府勤番日記』などの史料に屋敷替願の記事が散見される(p.1105 など）ことからも明らかと言ってよいだろう。

44）『萬代日記小若尾資料、山梨県立図霄館所藏。

45)もっとも、大河内が当初29番屋敷を洋領していた事実から考えると、史 料(3における「是」の対象は、鈴木のみならず湯川も含む、或いは鈴木 としたの讙りで実際は湯川であった、と考える方が自然なようにも思わ れるが、これ以上の判断材料がないため性急な結論は控えたい。

46) 安藤正人「近世甲府の都市構造と役負担」(『史料館研究紀要』第 13 号、 1981年 9 月)、p.214。

47) 安藤前揭諭文、p.141。

48）「富田富五郎墓銘」(教育資料人物部、「甲府市史」史料編第 4 巻 近世III、 pp.301-302)。

49)『御用日記』(坂田家文菖) 参照。

50) 内山县『甲将徽典館』(『甲府市史』史料編第 4 巻 近世 III 所収)、p.268。

51 ) 前揭『甲附徽典館』、p.267。

$52 ）$ 宮本定正『甲㪪廼手振』（嘉永 3 (1850)年序、若尾資料）。

53) 前揭『妇府徽典館』、p.269。

54) 前揭『蚫代日記』寛政 $9(1797)$ 年 6 月条にも既に「此度郭内追手小路於 医学所、来十一日より十人迄は不絶施涾㙩治致し候等二候間、内治・外 治・針治ともり療治受度もの八三・八之日朝五ッ時より四ッ時迄之内可 能出旨可相触事」との記事が見える。 